\title{
Echovirus 30 associated with cases of aseptic meningitis in state of Pará, Northern Brazil
}

\author{
Ceyla Maria Oeiras de Castro', Darleise S Oliveira', Olinda Macedo', Maria José L Lima², \\ Marquete B Santana², Ana Lucia Monteiro Wanzeller', Edna da Silveira', \\ Maria de Lourdes Contente Gomes ${ }^{1 /+}$
}

\footnotetext{
${ }^{1}$ Seção de Virologia, Instituto Evandro Chagas, Secretaria de Vigilância em Saúde, Ministério da Saúde, Rodovia BR 316 Km 07 s/n, 67030-000 Ananindeua, Pará, Brasil Unidade Básica de Saúde, Secretaria Executiva de Estado da Saúde do Pará, Belém, Pará, Brasil
}

Investigation of the aetiology of viral meningitis in Brazil is most often restricted to cases that occur in the Southern and Southeastern Regions; therefore, the purpose of this study is to describe the viral meningitis cases that occurred in state of Pará, Northern Brazil, from January 2005-December 2006. The detection of enterovirus (EV) in cerebrospinal fluid was performed using cell culture techniques, RT-PCR, nested PCR and nucleotide sequencing. The ages of the 91 patients ranged from < one year old to $>60$ years old (median age 15.90 years). Fever (87.1\%), headache (77.0\%), vomiting (61.5\%) and stiffness (61.5\%) were the most frequent symptoms. Of 91 samples analyzed, 18 (19.8\%) were positive for EV. Twelve were detected only by RT-PCR followed by nested PCR, whereas six were found by both cell culture and RT-PCR. From the last group, five were sequenced and classified as echovirus 30 (Echo 30). Phylogenetic analyses revealed that Echo 30 detected in Northern Brazil clustered within a unique group with a bootstrap value of $100 \%$ and could constitute a new subgroup (4c) according to the phylogenetic tree described by Oberste et al. (1999). This study described the first molecular characterization of Echo 30 in Brazil and this will certainly contribute to future molecular analyses involving strains detected in other regions of Brazil.

Key words: viral meningitis - enterovirus - Brazil

The enteroviruses (EVs) belong to the Picornaviridae family and the Enterovirus genus, which was recently divided into four species: Human enterovirus $A$ (HEV A) with 13 serotypes, HEV B (41 serotypes), HEV C (12 serotypes) and HEV D (2 serotypes) (Pallansch \& Roos 2007). The EVs are 28-30 nm in diameter and contain a capsid with icosahedral symmetry and a single molecule of positive-stranded RNA as their genome. The EV genome is a 7.4-7.5-kb single-stranded, polyadenylated RNA with a 22-amino acid virus-encoded protein (VPg) covalently linked to the 5 ' -end. Flanked by 5 '- and $3^{\prime}$ - nontranslated regions, the single, long open reading frame encodes a polyprotein of approximately 2,200 amino acids that is processed by viral proteinases to yield the mature viral polypeptides. The P1 region encodes the capsid proteins 1A-1D (VP1 VP4). The P2 region encodes a protease, $2 \mathrm{~A}$, and two proteins involved in RNA replication, $2 \mathrm{~B}$ and $2 \mathrm{C}$. $\mathrm{VPg}(3 \mathrm{~B})$ and its precursor ( $3 \mathrm{AB})$, the major viral protease (3C), and the RNAdependent RNA polymerase (3D) are encoded in the $\mathrm{P} 3$ region (Brown et al. 2003).

EVs are the most common cause of aseptic meningitis (AM), which is the most frequent central nervous system infection worldwide. Echovirus (Echo) types 4,

+ Corresponding author: lourdesgomes@iec.pa.gov.br Received 23 July 2008

Accepted 23 January 2009
13, 16 and 30 have been associated with outbreaks or epidemics in Panama, Cuba, the United States and Argentina (Reeves et al. 1987, Sarmiento et al. 2001, Kirschke et al. 2002, Freire et al. 2003, Grénon et al. 2008). In Brazil, the frequency of meningitis due to EVs was studied by Dos Santos et al. (2006) from 1998-2003. Among the 1,022 cerebrospinal fluids (CSFs) collected, 162 were positive for EVs with Echo 30 being identified in 139 $(85.8 \%)$ of them. In the past, polioviruses were detected in meningitis cases and Echo 9 was responsible for an outbreak of meningitis that occurred in São Paulo (SP) and Rio de Janeiro (RJ) in 1967 and 1978, respectively (Godoy et al. 1967, Nery-Guimarães et al. 1981). Other serotypes of Echo were found together with coxsackievirus B, EV 71 and no typed EV in cases of meningitis that occurred in three different Brazilian cities: Rio de Janeiro, RJ, Belém, state of Pará (PA) and Salvador, state of Bahia (BA) (Bedoya et al. 1998, Gomes et al. 2001, Ferreira et al. 2002, Silva et al. 2002, Lamarão et al. 2005, Gomes et al. 2007). In Brazil, Echo 30 has been associated with outbreaks and with frequent and sporadic cases of meningitis. In 1998, two outbreaks of AM occurred in the city of São Paulo, SP, and in Londrina, in the state of Paraná, Southeastern and Southern Regions of Brazil, respectively. In the city of São Paulo, 101 cases were isolated in 48 schools. Echo 30 was isolated in 57\% of the CSFs and $60 \%$ of the stool samples. In the city of Londrina, 411 cases were reported. Echo 30 was isolated in $43 \%$ of the 82 CSF samples and $67 \%$ of the 31 faecal specimens (Jóia et al. 1999, Timenetsky et al. 1999).

However, studies in Brazil of AM associated with EV were always restricted to the Southern and South- 
eastern Regions. The purpose of this study is to describe the meningitis cases that occurred in PA, North of Brazil, between January 2005-December 2006.

\section{MATERIAL AND METHODS}

Clinical specimen - CSF was collected at the Basic Health Unit (BHU) in the district of Pedreira, Belém, PA, from January 2005-December 2006 from patients presenting with classical symptoms of meningitis. These patients were from several cities in PA. It should be mentioned that the BHU is under the administration of the Public Health Department of State of Pará and is considered a reference centre for meningitis cases. CSFs were then divided into two aliquots: the first was used for cytochemical and microbiological analyses conducted at the BHU lab and the second was placed in liquid nitrogen and sent to Evandro Chagas for virus research.

Cells - The human embryonal rhabdomyosarcoma (RD) and the human epidermoid carcinoma of the larynx (HEp-2) cell lines were used in the detection of EV (Marchetti \& Gelfand 1963, Wecker \& ter Meulen 1997). RD and HEp-2 cells were maintained in Eagle Minimum Essential Medium containing Earle salts, L-glutamine, non-essential amino-acids, $10 \%$ foetal bovine serum and a mixture of penicillin and streptomycin.

EV isolation in cell culture - RD and HEp-2 cells were initially washed with $2 \mathrm{~mL}$ of Hank's BSS, inoculated with $200 \mu \mathrm{L}$ of $\mathrm{CSF}$ and incubated at $36^{\circ} \mathrm{C}$ during an hour for adsorption. After this time, $1 \mathrm{~mL}$ of medium was added. The tubes were incubated for nine (HEp-2) or seven (RD) days and checked daily for cytopathic effects. Positive samples were frozen before viral identification. A blind passage was performed for the RD negative tubes.

RNA extraction, RT-PCR and nested PCR from CSF samples - Viral RNA was extracted from the CSF using the QIAamp Viral RNA kit (QIAGEN GmbH, Hilden, Germany). RT-PCR was performed using previously described primers that recognized the 5' non-translated region of all known Evs (Zoll et al. 1992). The RT-PCR mixture contained water, buffer, 20 pmol of each primer, $200 \mu \mathrm{M}$ of dNTPs, $10 \mathrm{U}$ of RNase inhibitor, $1 \mathrm{mM}$ dithiothretol, $60 \mathrm{U}$ reverse transcriptase, $5 \mathrm{U}$ Taq polymerase and $20 \mu \mathrm{L}$ of extracted RNA in a final volume of 50 $\mu \mathrm{L}$. The resulting cDNA was used for EV amplification. This mixture was incubated for $60 \mathrm{~min}$ at $42^{\circ} \mathrm{C}$ and two min at $94^{\circ} \mathrm{C}$ for reverse transcription then subjected to 40 cycles of amplification consisting of $30 \mathrm{sec}$ of denaturation at $94^{\circ} \mathrm{C}, 30 \mathrm{sec}$ of annealing at $57^{\circ} \mathrm{C}$ and $30 \mathrm{sec}$ of extension at $72^{\circ} \mathrm{C}$. In order to improve the sensitivity of $\mathrm{EV}$ detection, a semi-nested PCR was also performed from CSF samples (Zoll et al. 1992). All products were applied to a $1.5 \%$ agarose gel, stained with ethidium bromide and visualized with UV light.

RNA extraction from cell culture supernatants - Viral RNA was extracted from RD and HEp-2 cell culture supernatants using the method described by Casas et al. (1995) with a few modifications. Initially, $200 \mu \mathrm{L}$ of cell culture supernatant was added to $400 \mu \mathrm{L}$ of the lysis buf- fer contained $4 \mathrm{M} \mathrm{GuSCN}$, 0.5\% N-lauroyl Sarcosine, 1 $\mathrm{mM}$ dithiothreitol, $25 \mathrm{mM}$ Sodium citrate and glycogen. After vigorous homogenization, the mixture was kept at RT for 10 min then quickly centrifuged. Six hundred microlitres of cold isopropanol $\left(-20^{\circ} \mathrm{C}\right)$ were added followed by another vigorous homogenization, incubation for five minutes at RT and centrifugation for $10 \mathrm{~min}$ at 13,000 $\mathrm{rpm}$ at $4^{\circ} \mathrm{C}$. After carefully removing the isopropanol, $500 \mu \mathrm{L}$ of $70 \%$ ethanol was added followed by another vigorous homogenization and centrifugation at 13,000 rpm for $10 \mathrm{~min}$ at $4^{\circ} \mathrm{C}$. Ethanol was carefully removed and the pellet was dried in a hot block at $60^{\circ} \mathrm{C}$ for $30 \mathrm{~min}$ then resuspended in $20 \mu \mathrm{L}$ of sterile distilled water and stored at $-20^{\circ} \mathrm{C}$ until its utilization in the RT- PCR test.

Genomic sequencing - For EV amplification and genotyping, primers 292 and 222 were used and were previously described by Oberste et al. (2003). These primers are directed against the VP1 region that encompasses the BC loop yielding amplicons approximately 357 nucleotides long. Three microlitres of template RNA were added to $47 \mu \mathrm{L}$ of a mix including 50 pmol of each primer, $200 \mu \mathrm{M}$ of each dNTP, $10 \mathrm{U}$ of RNase inhibitor, $1 \mu \mathrm{M}$ dithiothretol, $60 \mathrm{U}$ reverse transcriptase and 5 $\mathrm{U}$ Taq polymerase. The cycling profile involved reverse transcription at $50^{\circ} \mathrm{C}$ for $30 \mathrm{~min}$ and initial denaturation at $94^{\circ} \mathrm{C}$ for $3 \mathrm{~min}$ followed by 30 cycles with $30 \mathrm{sec}$ at $95^{\circ} \mathrm{C}, 30 \mathrm{sec}$ at $42^{\circ} \mathrm{C}$ and $30 \mathrm{sec}$ at $60^{\circ} \mathrm{C}$. All products were applied to a $1.5 \%$ agarose gel, stained with ethidium bromide and visualized with UV light.

RT-PCR products were purified using the PureLink ${ }^{\mathrm{TM}}$ PCR Purification Kit (Invitrogen, Carlsbad, CA) in accordance with the manufacturer's instructions. The nucleotide sequence was determined by direct cycle sequencing using the Big Dye Terminator Cycle Sequencing Ready Reaction Kit (Applied Biosystems) and primers 292 and 222. The purification of the amplicon was performed with isopropanol/ethanol $(75 / 70 \%)$. The products were analyzed on an automatic ABI Prism 3100 DNA Sequencer (Applied Biosystems). The nucleotide sequences determined in this study have been deposited in GenBank (http://www.ncbi.nlm.nih.gov) and assigned the accession numbers EU678965 to EU678969.

Computer-based genetic analysis - Sequence data from both strands were aligned and edited using the BioEdit Sequence Alignment Editor (v.7.0.5.2) program. Phylogenetic trees were constructed using MEGA software version 3.1 (Kumar et al. 2004) by the neighbour-joining (NJ) method. For NJ, a distance matrix was calculated from the aligned sequences by the Kimura 2-parameter formula (Kimura 1980). For determining the reliability of tree topology, bootstrap analysis (Felsenstein 1995) was carried out on 2,000 replicates.

\section{RESULTS}

Clinical epidemiological and laboratorial findings - From the 91 samples analyzed, 52 were collected in 2005 and 39 in 2006 . The positivity obtained was $19.8 \%$ (18/91) with $23.1 \%(12 / 52)$ in the first year and $15.4 \%$ (6/39) in the second year. In $41.8 \%$ of the cases, patients lived in Belém. The other patients lived in 26 other cities 
with Ananindeua (14 km) being closest to and Vizeu (336 $\mathrm{km}$ ) being farthest from Belém. After Belém, the greatest number of cases came from Ananindeua (8 cases), Castanhal (7), Barcarena (4) and Bragança (4) (Fig. 1).

Patients' ages varied from $<$ one year old (5 cases) to $>60$ years old ( 2 cases) with a mean age of 16.8 years old. The most common symptoms in patients were fever $(90.6 \%)$, headache $(83.2 \%)$, vomiting $(68.2 \%)$ and neck stiffness (57.0\%, data not shown).

Of $18(19.8 \%)$ EV-positive samples, 12 were found positive only by RT-PCR and six by both cell culture and RT-PCR (Table I). Information about origin, age, sex and cytochemistry of the samples is shown in Table I. The majority of the positive cases $(66.6 \%)$ came from different cities in PA and Belém contributed 33.3\% (6/18) of the cases. The age of the positive patients varied between three months and 48 years old (median age 16.3 years). Cytometry ranged from 17-1,024 cells of which $75 \%(12 / 16)$ of the samples had up to 500 cells. With respect to cytology, a variety of lymphocytes between $68-96 \%$ was found in 16 samples with seven of them showing a percentage higher than or equal to $90 \%$. With regard to glucose, a value equal to or higher than $50 \mathrm{mg}$ was observed in $54 \%$ of the samples. Concerning protein concentration, $35.7 \%$ of the samples showed values above $50 \mathrm{mg}$ and $64.3 \%$ below $50 \mathrm{mg}$. Fig. 2 shows that the monthly distribution of the $18 \mathrm{EV}$-positive cases occurred throughout the study period beginning in August 2005. In some months, such as February, March and May 2005, no case of viral meningitis was registered.

Partial sequencing of the VPI gene in Echo 30 samples - To analyze genetic diversity and molecular aspects of Echo 30, partial nucleotide sequences (349 bp) of the VP1-encoding gene from five samples isolated in 2005 and 2006 in Northern Brazil from patients with the symptoms of viral meningitis were used. In order to make comparisons, 50 Echo 30 strains and the Echo 21 prototype strain Farina, all of which have been sequenced and are found in GenBank, were included in the analyses. The Brazilian samples were isolated in five different cities in PA: Belém (Echo 30 BR2005-012-02), Abaetetuba (Echo 30 BR2005-023-11), Nova Timboteua (Echo 30 BR2006-08-01), Castanhal (Echo 30 BR200607-02), and Ananindeua (Echo 30 BR2006-111-04). Belém is the capital of PA, while the others are the main population centres of municipalities found at different distances from Belém, the farthest one being Nova Timboteua, located $141 \mathrm{~km}$ from Belém.

In accordance with Oberste et al. (1999), there are four distinctive genetic groups of Echo 30 that are designated as 1, 2, 3 and 4 (subgroups $4 \mathrm{a}$ and $4 \mathrm{~b}$ ). Using this classification, Brazilian samples presented a quite cohesive group with $100 \%$ bootstrap (Fig. 3). The samples showed $98.5 \%$ nucleotide homology among themselves with a mean divergence of $1.5 \%$. The sample Echo 30 BR2005-023-11 showed the highest divergence (2-3.2\%) among the Brazilian samples. These strains showed stronger genetic affinity $(89.4 \%)$ with the strains that belong to the genetic subgroup $4 \mathrm{~b}$ ( $62 \%$ bootstrap), but the strains AUS 96 and AUS 97 belonging to this group presented a homology of only $87.4 \%$. The comparison of the PA strains with the prototype Bastianni strain showed a homology of $75.9-76.3 \%$ in the nucleotide sequence. In relation to the other groups, observed homology values were $69.7 \%$ (group 1), $80.6 \%$ (group 2), $84.5 \%$ (group 3) and $86.9 \%$ (subgroup $4 a$ ). The Farina Echo 21 strain showed a nucleotide homology of $67.5 \%$.

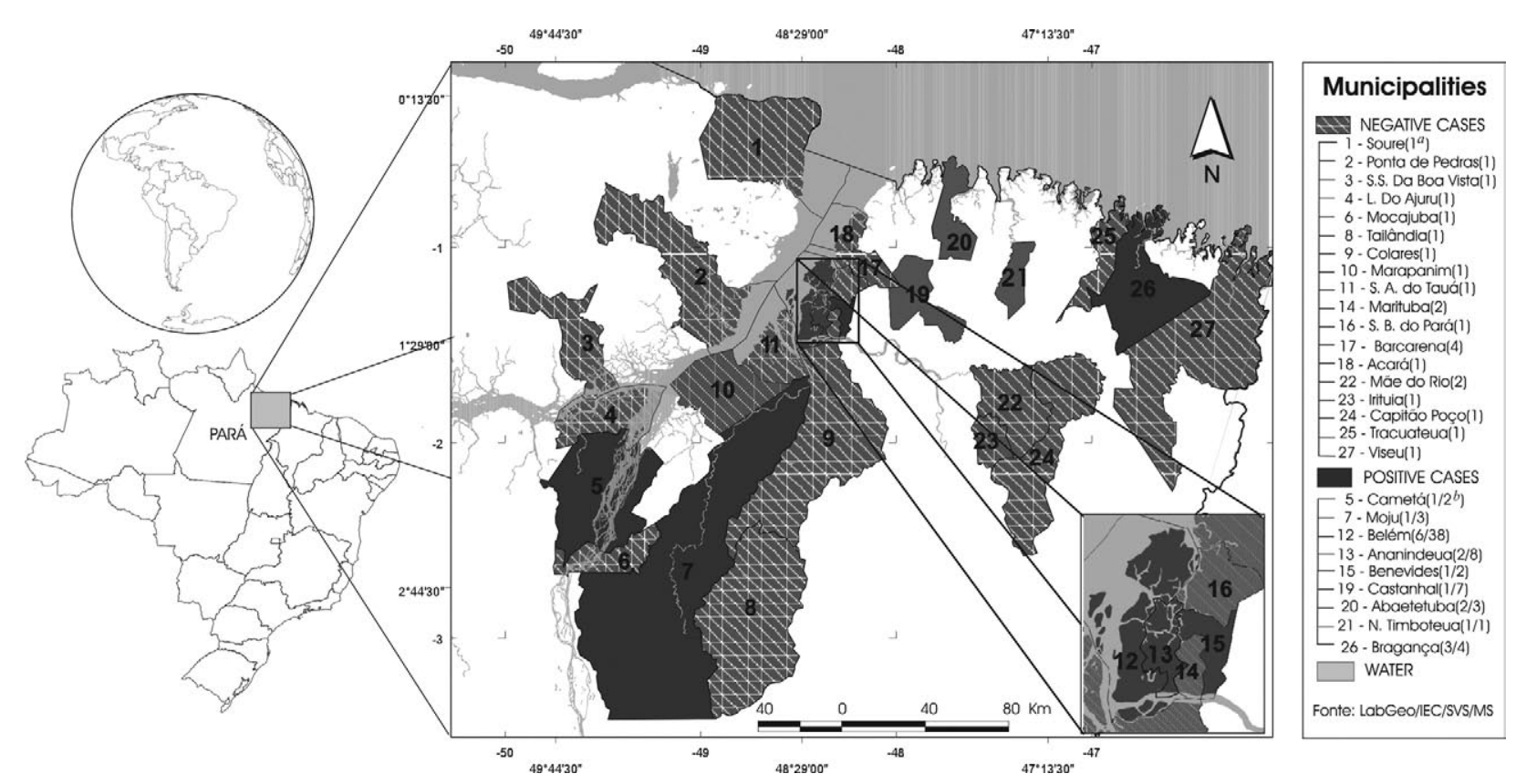

Fig. 1: map of the state of Pará, Brazil, showing the location of the occurrence of the meningitis cases. $a$ : total of cases; $b$ : positive cases/ number of cases. 
TABLE I

Epidemiological and laboratorial findings found in the 18 cases of viral meningitis that were positive for enterovirus

\begin{tabular}{|c|c|c|c|c|c|c|c|c|c|c|}
\hline \multirow{2}{*}{\multicolumn{2}{|c|}{ Basic Health Unit }} & \multirow[b]{2}{*}{ Place of origin } & \multirow[b]{2}{*}{ Age/sex } & \multicolumn{5}{|c|}{ CSF cytochemistry } & \multicolumn{2}{|c|}{ Result } \\
\hline & & & & $\begin{array}{l}\text { Leuco } \\
\mathrm{mm}^{3}\end{array}$ & $\begin{array}{c}\text { Neutro } \\
\%\end{array}$ & $\begin{array}{c}\text { Lymph } \\
\%\end{array}$ & $\begin{array}{l}\text { Gluco } \\
\text { mg }\end{array}$ & $\begin{array}{l}\text { Prot } \\
\text { mg }\end{array}$ & RT-PCR & Cell cult \\
\hline 01 & $117-08 / 05$ & Moju & $3 \mathrm{mth} / \mathrm{F}$ & NA & NA & NA & NA & NA & + & - \\
\hline 02 & $054-09 / 05$ & Cametá & $16 y / F$ & 224 & 4 & 96 & 44 & 60 & + & - \\
\hline 03 & $060-09 / 05$ & Benevides & $14 \mathrm{y} / \mathrm{M}$ & 224 & 32 & 68 & 50 & 33 & + & - \\
\hline $04^{a}$ & $012-10 / 05$ & Belém & $4 y / M$ & 88 & 30 & 70 & 66 & 30 & + & + \\
\hline 05 & $076-10 / 05$ & Bragança & $45 \mathrm{y} / \mathrm{M}$ & NA & NA & NA & NA & NA & + & - \\
\hline 06 & 077-10/05 & Belém & $18 \mathrm{y} / \mathrm{M}$ & 330 & 10 & 90 & 38 & 45 & + & - \\
\hline 07 & 093-10/05 & Belém & $37 \mathrm{y} / \mathrm{F}$ & 850 & 4 & 96 & 38 & 75 & + & - \\
\hline 08 & $006-11 / 05$ & Bragança & $18 \mathrm{y} / \mathrm{M}$ & 282 & 25 & 75 & 56 & 36 & + & - \\
\hline $09^{a}$ & $023-11 / 05$ & Abaetetuba & $4 y / F$ & 33 & 8 & 92 & 80 & 19 & + & + \\
\hline 10 & $054-11 / 05$ & Belém & $8 \mathrm{y} / \mathrm{M}$ & 17 & 5 & 95 & NA & 3 & + & - \\
\hline 11 & $059-11 / 05$ & Ananindeua & $7 y / M$ & 277 & 5 & 95 & NA & 89 & + & - \\
\hline 12 & 071-11/05 & Abaetetuba & $5 y / M$ & 341 & 12 & 88 & NA & 81 & + & - \\
\hline $13^{a}$ & 008-01/06 & N. Timboteua & $5 y / M$ & 261 & 14 & 86 & NA & 79 & + & + \\
\hline 14 & 087-01/06 & Belém & $14 y \mathrm{M}$ & 1024 & 22 & 78 & 74 & 47 & + & + \\
\hline $15^{a}$ & 007-02/06 & Castanhal & NA/M & 507 & 39 & 61 & NA & NA & + & + \\
\hline $16^{a}$ & $111-04 / 06$ & Ananindeua & $48 \mathrm{y} / \mathrm{F}$ & 597 & 31 & 69 & 52 & 41 & + & + \\
\hline 17 & 074-08/06 & Bragança & $29 y / F$ & 346 & 10 & 90 & 45 & 48 & + & - \\
\hline 18 & 041-11/06 & Belém & $6 y / M$ & 357 & 30 & 70 & 40 & NA & + & - \\
\hline
\end{tabular}

a: samples sequenced and classified as Echo 30; F: female; M: male; mth: months; NA: data not available; y: year.

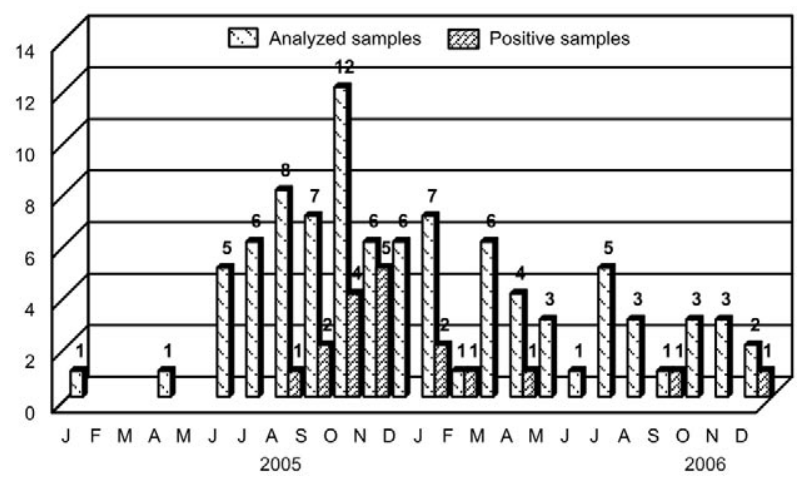

Fig. 2: monthly distribution of 18 entrovirus samples detected in 91 cases of viral meningitis, in state of Pará, Brazil, from January 2005-December 2006.

Concerning the amino acid sequences, the Brazilian samples showed $100 \%$ similarity among themselves. When compared to the Bastianni strain, the similarity reached approximately $91.9 \%$. The highest percentage of similarity in the Brazilian samples (98.6\%) was to subgroup $4 \mathrm{~b}$. Different percentages of similarity were found with the other genetic groups: $89.3 \%$ (group 1), 94.3\% (group 2), $97.2 \%$ (group 3) and $97.6 \%$ (subgroup 4a). This similarity decreased to $77.7 \%$ when compared to the Farina Echo 21 strain.

Such a high degree of amino acid similarity between the isolated Brazilian strains and the Bastianni prototype strain indicates that a large number of the nucle- otide substitutions were silent, occurring predominantly in the second nucleotide of each codon and leading to synonymous substitutions. Nine nucleotide substitutions were observed that lead to a change of amino acid (nonsynonymous) (Table II). The amino acid A602 found in the Brazilian samples was not found in any of the other Echo 30 strains analyzed in this study. In addition to the previously mentioned substitutions, the Echo 30 BR2005-023-11 sample showed four substitutions related to the Bastianni prototype strain, an occurrence not observed in the other Brazilian samples: 1: nt 1845 (A > G); 2: nt $2040(\mathrm{G}>\mathrm{T}) ; 3$ : nt $2064(\mathrm{~T}>\mathrm{C})$ and 4: nt 2085 $(C>T)$, which were all synonymous.

\section{TABLE II}

Nucleotide substitutions leading to amino acid changes (non-synonymous) observed in the Brazilian samples with compared to the Bastianni strain

\begin{tabular}{ccccc}
\hline $\mathrm{N}$ & Nucleotide & $\begin{array}{c}\text { Substitution } \\
\text { (change) }\end{array}$ & Amino acid & $\begin{array}{c}\text { Substitution } \\
\text { (change) }\end{array}$ \\
\hline 1 & 1805 & $\mathrm{~T} \rightarrow \mathrm{C}$ & 602 & $\mathrm{~V} \rightarrow \mathrm{A}$ \\
2 & 1871 & $\mathrm{~T} \rightarrow \mathrm{A}$ & 624 & $\mathrm{~F} \rightarrow \mathrm{Y}$ \\
3 & 1894 & $\mathrm{~T} \rightarrow \mathrm{A}$ & 632 & $\mathrm{~L} \rightarrow \mathrm{I}$ \\
4 & 1938 & $\mathrm{C} \rightarrow \mathrm{G}$ & 646 & $\mathrm{H} \rightarrow \mathrm{Q}$ \\
5 & 1955 & $\mathrm{C} \rightarrow \mathrm{T}$ & 652 & $\mathrm{~A} \rightarrow \mathrm{V}$ \\
6 & 1965 & $\mathrm{~T} \rightarrow \mathrm{G}$ & 655 & $\mathrm{D} \rightarrow \mathrm{E}$ \\
7 & 2099 & $\mathrm{~A} \rightarrow \mathrm{C}$ & 700 & $\mathrm{~N} \rightarrow \mathrm{T}$ \\
8 & 2102 & $\mathrm{G} \rightarrow \mathrm{C}$ & 701 & $\mathrm{R} \rightarrow \mathrm{T}$ \\
9 & 2137 & $\mathrm{~A} \rightarrow \mathrm{G}$ & 713 & $\mathrm{I} \rightarrow \mathrm{V}$ \\
\hline
\end{tabular}




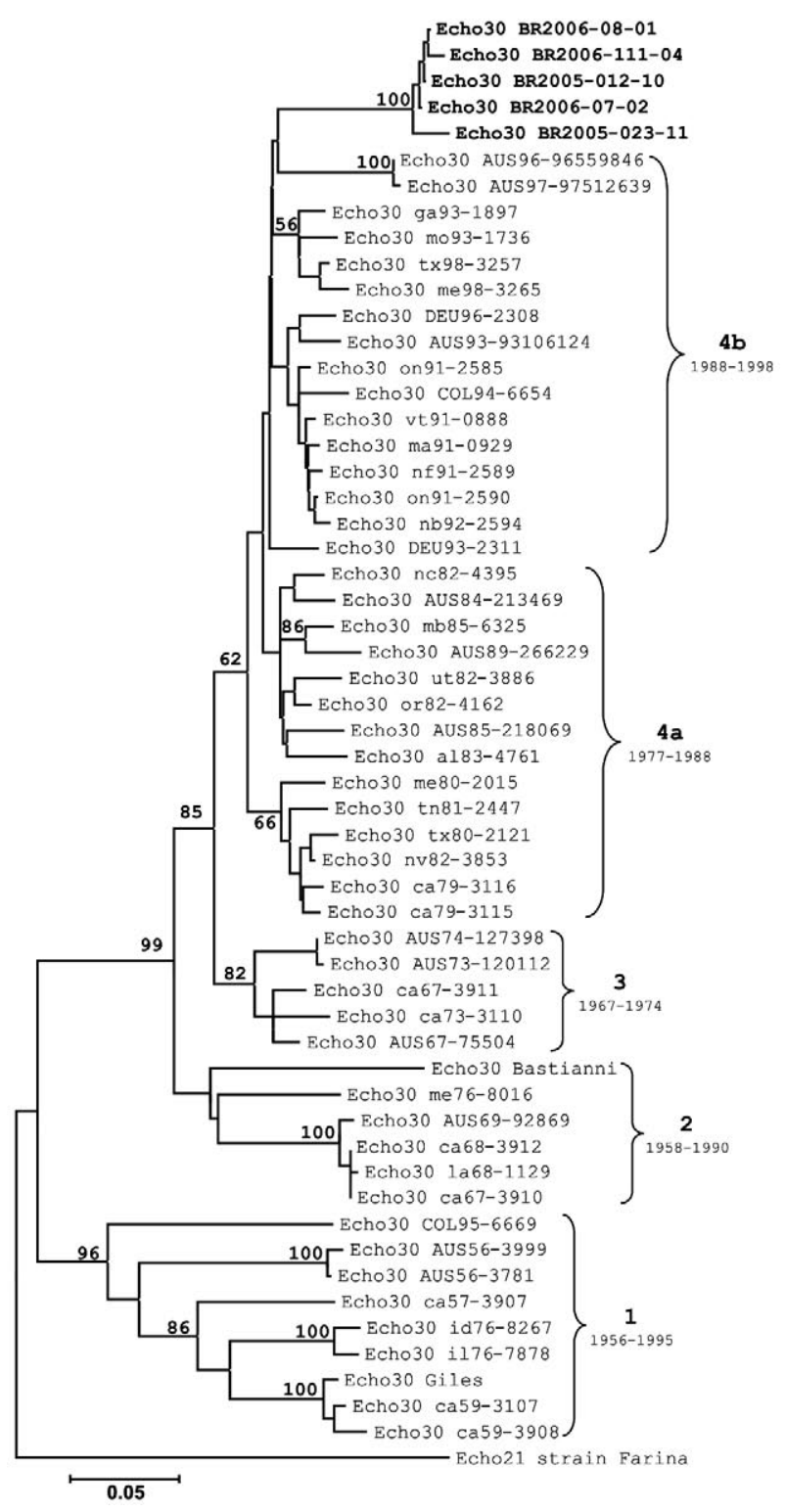

Fig. 3: dendrogram based on the alignment of the virus-encoded protein-1 gene nucleotide sequences ( $349 \mathrm{pb}$ ) showing genetic affinity of the Echovirus (Echo) 30 samples of Belém, state of Pará, with Echo 30 strains from other countries and the Bastianni strain (prototype). The Echo 21 Farina strain was used as "outgroup".

\section{DISCUSSION}

The positivity rate of $19.7 \%$ obtained in this study for EV was similar to the $21.8 \%$ detected in CSF samples of patients with meningitis from a hospital in RJ (Bedoya et al. 1998).

The percentages of $6.5 \%$ and $19.7 \%$ detected in cell culture and RT-PCR, respectively, were lower than the $16.2 \%$ and $38.4 \%$ observed in a study that involved 52 CSF samples from Greece in cases from March 2003-April 2005 (Dumaidi et al. 2006).

In this study, only one HEV serotype, Echo 30, was detected. From 2000-2002 in Cyprus, 10 different EV serotypes were detected in 218 cases of enteroviral meningitis, with $55.5 \%$ of them caused by Echo $30,15.2 \%$ by Echo 13,13.8\% by Echo 6 and 8.3\% by Echo 9 (Richter et al. 2006). Six different HEV serotypes were found in Salvador between September 1997-March 2000 in 112 cases of meningitis in which Echo 4 was predominant (Silva et al. 2002). It is worth mentioning that in both studies, CSF and faecal samples were used for serotype detection. This might have contributed to the increase in serotype detection. On the other hand, a study conducted in four of the five Brazilian regions identified eight EV serotypes (Echo 30, Cox B5, Echo 13, Echo 18, Echo 6, Echo 25, Echo 1 and Echo 4) in the 162 CSF samples collected from viral meningitis cases (Dos Santos et al. 2006). It is likely that a similar diversity in serotypes could be found in this study if the 12 positive HEV samples found by RT-PCR were identified.

In this study, all samples that were identified as positive in cell culture were also identified by RT-PCR, differing from the results described by Henquell et al. (2001) in which two cases that were positive in cell culture were negative by PCR. It is possible that the DNA might have degraded during preparations.

The CSF results for cell count and protein concentration obtained in this study were similar to those found in Salvador (1997-2000) and Belém (2002-2003) in cases of AM, but differed in relation to glucose dosage. In this study, $54 \%$ of the samples showed a glycorachia value $\geq 50 \mathrm{mg} / \mathrm{dL}$. In studies by Silva et al. (2002) and Lamarão et al. (2005), this value was $76.6 \%(>50 \mathrm{mg} / \mathrm{dL})$ and $33.3 \%$ (> $53 \mathrm{mg} / \mathrm{dL}$ ), respectively It is likely that the use of different experimental procedures might have influenced these results.

A seasonal pattern of occurrence was not observed over the two years of the survey, with positive cases being detected throughout the period of study. A different pattern was described in a study involving samples from other Brazilian regions in which there was a tendency for cases to occur during a period of high temperature (Dos Santos et al. 2006).

Comparative analyses of the VP1 region genomic sequences - The EV detected in this study were serotyped using a pair of primers specific for the VP1 region that allows a clear identification of these serotypes as demonstrated previously in other studies (Oberste et al. 1999, Thoelen et al. 2003). It was possible to detect the enteroviral genome in $19.8 \%$ of the CSF samples using primers 2, 3 and 10; however, such oligos have not been used previously in serotype identification because the nucleotide sequences come from a conserved region used for identifying EV gender. Primers 292 and 222 were used to amplify a fragment from a variable region of the genome (VP1 protein) for serotyping. However, this method was only successful when these primers were used in RNA extracted from cell fluid and never from CSF. New pairs of primers will be developed with the purpose of identifying new EVs.

This study reports the first molecular characterization of Echo 30 in specimens collected from viral meningitis cases in Brazil. These strains were also compared 
with other Echo 30 strains found elsewhere. Using the classification system described by Oberste et al. (1999), it was noted that all the strains detected in PA, together with the ones from Australia (1996-1997), probably constituted a new subgroup (4c), independent of subgroup $4 \mathrm{~b}$ (Fig. 3), with a divergence of $10.6 \%$. Such distinctive molecular characteristics of the Brazilian samples suggest that the cases of viral meningitis that occurred in Northern Brazil were caused by an Echo 30 variation, thus allowing for the proposal that a subgroup be added to the dendrogram topology.

The greatest divergence observed with PA strains was to group 1 with values of $30.3 \%$ for the nucleotide sequences and $10.7 \%$ for amino acid sequences. These results were similar to the ones described by Oberste et al. (1999), with $26.4 \%$ and $13 \%$ for nucleotides and amino acids, respectively.

The strains detected during an outbreak in Taiwan (Wang et al. 2002), when compared with groups 1, 2, 3, $4 \mathrm{a}$ and $4 \mathrm{~b}$, showed values of divergence similar to the ones detected in the strains from PA. However, a nucleotide divergence of $13.1 \%$ was observed when a comparison was made between PA and Taiwan strains. The same value was noted when the strains of PA were compared with subgroup 4a.

The PA samples showed $100 \%$ similarity in their sequences, confirming the monophyletic aspect of the Echo 30.

The data presented in this study will certainly be an important contribution to delineating a general picture of viral meningitis in Brazil. As this is the first characterization of Echo 30 in Brazil, further studies with other specimens will be necessary in order to characterize the genetic diversity of the Echo circulating in Brazil.

\section{ACKNOWLEDGMENTS}

To Lyla de Araujo Rayol, for helping with English, to Dr. Yvone Gabbay Mendes, for the revision and suggestions, and to Dr. Nelson Veiga, from the Geoprocessing Section, for the preparation of the map.

\section{REFERENCES}

Bedoya SP, Trocoli MGC, Da Silva EE, Leite JPG 1998. Detection of virus by polymerase chain reaction in cases of acute meningitis. Virus Rev Res 3 (Suppl.1): 98.

Brown B, Oberste MS, Maher K, Pallansch MA 2003. Complete genomic sequencing shows that polioviruses and members of human enterovirus species $\mathrm{C}$ are closely related in the noncapsid coding region. $J$ Virol 77: 8973-8984.

Casas I, Powell I, Klapper PE, Cleator GM 1995. New method for the extraction of viral RNA and DNA from cerebrospinal fluid for use in the polymerase chain reaction assay. $J$ Virol Methods 53: 25-36.

Dos Santos GPL, Skraba I, Oliveira D, Lima AAF, Melo MMM, Kmetzsch CI, Costa EV, Da Silva EE 2006. Enterovirus meningitis in Brazil, 1998-2003. J Med Virol 78: 98-104.

Dumaidi K, Frantzidou F, Papa A, Diza E, Antoniadis A 2006. Enterovirus meningitis in Greece from 2003-2005: diagnosis, CSF laboratory findings and manifestations. J Clin Lab Anal 20: 177-183.

Felsenstein J 1995. PHYLIP, Version 3.57c. Department of Genetics, University of Washington, Seatle, WA.

Ferreira LLA, Lamarão LM, Santos MC, Fonseca CMF, Araújo LCB,
Santana MB, Gomes MLC 2002. Detecting of enterovirus (EV) in cases of aseptic meningitis (AM) occurred in Belém, Pará, Brazil. Virus Rev Res 7: 146.

Freire MC, Cisterna DM, Rivero K, Palácios GF, Casas I, Tenório A, Gómez JA 2003. Analysis of an outbreak of viral meningitis in the province of Tucuman, Argentina. Rev Panam Salud Publica 13: 246-251.

Godoy CVF, Carvalho RPS, Kirchner E, Pereira OAC, Aguiar-Pupo A 1967. Síndrome de meningite asséptica. Esclarecimento etiológico de alguns casos na cidade de São Paulo. Considerações clínico-laboratoriais. Rev Inst Med Trop São Paulo 9: 213-221.

Gomes MLC, Ferreira LLA, Gomes RH, Lamarão LM, Silveira E, Rodrigues LS, Silva CF, Almeida ER 2007. RT-PCR for confirmation of Echovirus 30 isolated in Belém, Brazil. Braz J Infect Dis 11: 403-406.

Gomes MLC, Kopecka H, Linhares AC 2001. Detection of enteroviruses in cases of neurological disorders in the state of Pará, Brazil. Rev Inst Med Trop São Paulo 43: 321-324.

Grenón SL, Robledo ML,von Specht MH, Cisterna DM, Lema CL, Freire MC 2008. Outbreak of viral meningitis caused by echovirus type 4 in Misiones province. Rev Argent Microbiol 40: 41-46.

Henquell C, Chambon M, Baily J-L, Alcaraz S, De Champs C, Archimbaud C, Labbé A, Charbonné F, Peigue-Lafeuille H 2001. Prospective analysis of 61 cases of enteroviral meningitis: interest of systematic genome detection in cerebrospinal fluid irrespective of cytologic examination results. J Clin Virol 21: 29-35.

Jóia AEB, Figueiredo MH, Skaba I, Ribeiro M, Ribeirette MR, Takemura NS, Melo VO, Costa EV, Da Silva EE 1999. A large outbreak of aseptic meningitis caused by echovirus 30 in Paraná, Brazil. Virus Rev Res 4 (Suppl. 1): 141.

Kimura M 1980. A simple method for estimating evolutionary rate of base substitution through comparative studies of nucleotide sequences. J Gen Virol 77: 1761-1768.

Kirschke DL, Jones TF, Buckingham SC, Grig AS, Schaffner W 2002. Outbreak of aseptic meningitis associated with echovirus 13. Pediatr Infect Dis J 21: 1034-1038.

Kumar S, Tamura A, Nei M 2004. MEGA 3: integrated software for molecular evolutionary genetic analysis and sequence alignment. Brief Bioinform 5: 150-160.

Lamarão LM, Gomes MLC, Ferreira LLA, Fonseca CM, Araújo LCB, Santana MB, Tavares-Neto J 2005. Pesquisa de enterovírus em casos de síndrome de meningite asséptica de Belém. Rev Soc Bras Med Trop 38: 391-395.

Marchetti GE, Gelfand HM 1963. Use of HEP-2 cells for grouping enteroviruses. Public Health Rep 78: 813-818.

Nery-Guimarães R, Bittencourt LCM, Pastor MVA 1981. As meningites virais no município do Rio de Janeiro, RJ (Brasil), 1978. Rev Saude Publica 15: 455-471.

Oberste MS, Maher K, Kennett ML, Campbell JJ, Carpenter MS, Schnurr D, Pallansch MA 1999. Molecular epidemiology and genetic diversity of Echovirus type 30 (E30): genotypes correlate with temporal dynamics of E30 isolation. J Clin Microbiol 37: 3928-3933.

Oberste MS, Nix AW, Kaija M, Pallansch MA 2003. Improved molecular identification of enteroviruses by RT-PCR and amplicon sequencing. J Clin Virol 26: 375-377.

Pallansch M, Roos R 2007. Enteroviruses: polioviruses, coxsackieviruses, echoviruses, and newer enteroviruses. In DM Knipe, DE Griffin, RA Lamb, SE Strauss, PM Howley, MA Martin, B Roizman (eds.), Fields Virology, 5th ed., Williams \& Wilkins, Philadelphia, p. 839-893. 
Reeves WC, Quiroz E, Brenes MM, Centeno R, Campos G 1987. Aseptic meningitis due to echovirus 4 in Panamá city, Republic of Panamá. Am Journal Epidemiol 125: 562-575.

Richter J, Koptides D, Tryfonos C, Christodoulou C 2006. Molecular typing of enteroviruses associated with viral meningitis in $\mathrm{Cy}-$ prus, 2000-2002. J Med Microbiol 55: 1035-1041.

Sarmiento L, Mas P, Goyenechea A, Palomera R, Morier I, Capó V, Quintana I, Santin M 2001. First epidemic of Echovirus 16 neningits in Cuba. Emerg Infect Dis 7: 887-889.

Silva HR, Tanajura GM, Tavares-Neto J, Gomes MLC, Linhares AC, Vasconcelos PFC, Ko AI 2002. Síndrome de meningite asséptica por enterovírus e Leptospira sp em crianças de Salvador, Bahia. Rev Soc Bras Med Trop 35: 159-162.

Thoelen I, Lemey P, Van Der Donck I, Beuselinck K, Lindberg AM, Van Ranst M 2003. Molecular typing and epidemiology of en- teroviruses identified from an outbreak of aseptic meningitis in Belgium during the summer of 2000. J Med Virol 70: 420-429.

Timenetsky MCST, Carmona RCC, Machado BC, Santana RAR, Fernandes KC 1999. Aseptic meningitis by echovirus 30 in São Paulo state. Virus Rev Res 4 (Suppl. 1): 118.

Wang JR, Huey-Pin T, Sen-Wen H, Pin-Hwa K, David K, ChingChuan L 2002. Laboratory diagnosis and genetic analysis of an Echovirus 30- associated outbreak of aseptic meningitis in Taiwan in 2001. J Clin Microbiol 40: 4439-4444.

Wecker I, ter Meulen V 1997. RD cells in the laboratory diagnosis of enteroviruses. Med Microbiol Immunol 163: 233-240.

Zoll GJ, Melchers WJG, Kopecka H, Jambroes G, van der Poel HJA, Galama JMD 1992. General primer-mediated polymerase chain reaction for detection of enteroviruses: application for diagnostic routine and persistent infections. J Clin Microbiol 30: 160-165. 